\title{
Development of a Preschool Teachers' Pedagogical Content Knowledge Scale regarding Mathematics
}

\author{
Hatice Dağlı (iD) 1,* , H. Elif Dağlığlu (D) ${ }^{1}$, E. Hasan Atalmış (D) 1
}

${ }^{1}$ Kahramanmaraş Sütçü İmam University, Department of Preschool Education, Turkey

${ }^{2}$ Gazi University, Department of Preschool Education, Turkey

${ }^{3}$ Kahramanmaraş Sütçü İmam University, Department of Measurement and Evaluation in Education, Turkey

\author{
ARTICLE HISTORY \\ Received: 18 July 2019 \\ Revised: 07 October 2019 \\ Accepted: 05 December 2019
}

\section{KEYWORDS}

Mathematics education,

Preschool teacher,

Pedagogical content

knowledge

\begin{abstract}
This study aimed to develop a measurement tool in order to assess preschool teachers' pedagogical content knowledge regarding mathematics. The study was based on 300 preschool teachers working in formal independent kindergartens and nursery classes of primary/secondary schools in the Kahramanmaraş Province of Turkey. Among the participants, 150 were chosen for pre-application and 150 for the main application. The scale consists of five different case studies and a total of 35 items, including dialogues that focus on mathematical content and processes reflected in children's talk during their play. In calculating the reliability of the scale, Cronbach Alpha was found to be .95 for the pre-application and .96 for the main application. For the validity of the scale, exploratory and confirmatory factor analyses were performed. The exploratory factor analysis results revealed the scale to be a single-factor structure. When the factor loads of each relevant item were examined, no item was found to exist with a factor load value of less than .30 . After confirmatory factor analysis was performed, the model fit indices of CFI, TLI, RMSEA, and SRMR values were found to be $.91, .91, .06$ and .06 , respectively. These results show the model to be reliable to an acceptable level. Based on the findings, it could be concluded that the scale is an instrument that produces valid and reliable measures, and that it can be used in order to determine the preschool teachers' pedagogical content knowledge regarding mathematics.
\end{abstract}

\section{INTRODUCTION}

Mathematics and mathematical thinking have been regarded as key skills of our time in terms of their scientific field. The development of mathematical competencies begins at birth (Anthony \& Walshow, 2009; Çoban, 2002). Mathematics is a field containing important concepts and skills which are widely used in learning processes and particularly in daily life. As people interact with their environment in daily life, they encounter various concepts such as time, space, shapes, and numbers, and therefore interact with mathematics without even realizing it (Bulut \& Tarım, 2006). Understanding mathematics provides children with the ability to solve problems and to make correct decisions. Mathematics knowledge requires many

CONTACT: Hatice Dağlı $\bowtie$ hnddagli@hotmail.com $\equiv$ Kahramanmaraş Sütçü İmam University, Department of Preschool Education, 46100, Kahramanmaraş, Turkey 
skills such as establishing cause-effect relationships, making calculations, calculating time, money management, and the use of technology (Ontario Ministry of Education [OME], 2014).

Researchers who conduct studies on cognitive development have revealed that the early development of mathematical skills closely relates to children's academic achievement in subsequent years (Anders \& Rossbach, 2015; Aunola, Leskinen, Lerkkanen, \& Nurmi, 2004; Clements, Sarama, \& DiBiase, 2004; Gersten et al., 2009). Mathematics is a particularly hierarchical subject, in which mastery of simple concepts and procedures is required in order to understand more difficult mathematics (Watts, Duncan, Clements, \& Sarama, 2017). It is of significant importance to teach mathematics that children will use and encounter throughout their lives (OME, 2014). In this regard, the early childhood years are particularly vital as the starting point for children to encounter formal mathematics education and basic mathematical concepts; moreover, mathematical skills are also learned within this period. The aim of mathematics education at the preschool level is to provide children with meaningful experiences through gameplay, stories, music and physical activities; to create them a sense of success with appropriate materials in appropriate physical environments, and to support the development of mathematics skills without creating a negative attitude towards mathematics (Arnas, 2006; Dağlı \& Dağlığlu, 2017; Henniger, 1987; Metin, 1994; Mononen, Aunio, \& Koponen, 2014). Thus, the preschool period is considered to the magical years where children's love for mathematics is inculcated and nurtured, and for the development of a positive attitude towards mathematics.

Some experimental studies on mathematical concepts and skills in the preschool period depicted that mathematical applications performed with children may create positive differences in their mathematical competencies when they start primary school, and that these differences last throughout their school life and even beyond (Anders, Grosse, Rossbach, Ebert, \& Weinert, 2013; Sammons et al., 2004). In this context, mathematics literacy and mathematics skills are important not only for children's school success, but also in terms of their professional career throughout adulthood (Anders \& Rossbach, 2015; Clements et al., 2004). Mathematics education presented to children during their preschool period is significant for their ability to achieve successful mathematical thinking in the following years and in their readiness preparation for primary schooling (Claesens \& Engel, 2013; Dağlığlu, Dağl1, \& Kılıç, 2013). When considered in the long term, understanding mathematics is so effective that it can direct children towards their future work life and career (Ontario Ministry of Education, 2014).

When it comes to the significance of early mathematics education, recent studies have emphasized that such education should be structured appropriately to the nature of the child; and that the child should reach the information by doing and experiencing personally, rather than teachers attempting to transfer knowledge directly to the child (Arnas, 2006; National Council of Teachers of Mathematics [NCTM], 2000). In other words, it is necessary for children to encounter the experiences in which they will learn mathematics concepts by doing and experiencing during their preschool period (Clements \& Sarama, 2014; Umay, 2003).

The recent studies have also suggested that activities prepared in accordance with children's interests and their motivation can have a significant effect on their future success (Baranek, 1996; Berhenge, 2013; Mokrova, 2012; Tella, 2007). Education given in subjects or areas that children are interested in has a more lasting effect (Fisher, 2004). In this regard, mathematics content can and should play a significant role in early childhood education.

Different research on mathematics education during the preschool period has been conducted in many different countries. In the Turkish Preschool Education Program, which was updated in 2013, it is emphasized that mathematics education contributes to the cognitive development of children, that mathematics education within the preschool period can bestow positive attitudes in children, and that the mathematical inquiry skills of children can be improved 
through mathematics-based activities (Milli Eğitim Bakanlığı [Turkish Ministry of National Education], 2013). In addition, mathematical activities that establish relationships between concepts and life skills should be included in preschool education programs and that childcentered, game-based and multifaceted activities should be planned.

High quality, interesting and accessible mathematics education for the 3-6-year-olds age group was emphasized through situational assessments undertaken jointly by the National Association for the Education of Young Children in America and the NCTM (2010). In particular, the NCTM emphasized that educational programs which are well-planned, comprehensive, suitable for children's development, and meet the required language skills within a cultural context will be more effective (NCTM, 2009, 2013). Accordingly, mathematical understanding, knowledge and skills need to be gained during the education period starting from preschool. The NCTM (2009) also set content and process standards; defined the concepts and contents that children should learn through the content standards, and concept and content knowledge acquisition as well as using methods information through the process standards. When based on mathematics education, the NCTM (2000) showed that mathematical activities and mathematical content such as numbers, operations, geometry and measurement should be integrated with process standards such as problem solving, reasoning and proof, association, communication and symbolization. This process showed that mathematics program and education practices should be structured on a sound basis by taking into account both mathematical content areas and the developmental characteristics of children.

Considering that pedagogical approaches supporting the development of mathematical skills are seen as effective in enhancing these skills in children (Mononen \& Aunio, 2013); the importance of teachers' pedagogical content knowledge related to mathematics has become prominent (Gifford, 2005). Pedagogical content knowledge in education was originally proposed by Shulman (1986), and encompasses knowing what to teach according to age groups and integrating that with the knowledge of how to teach it.

McCray (2008) explained the factors affecting pedagogical content knowledge regarding mathematics, as illustrated in Figure 1.

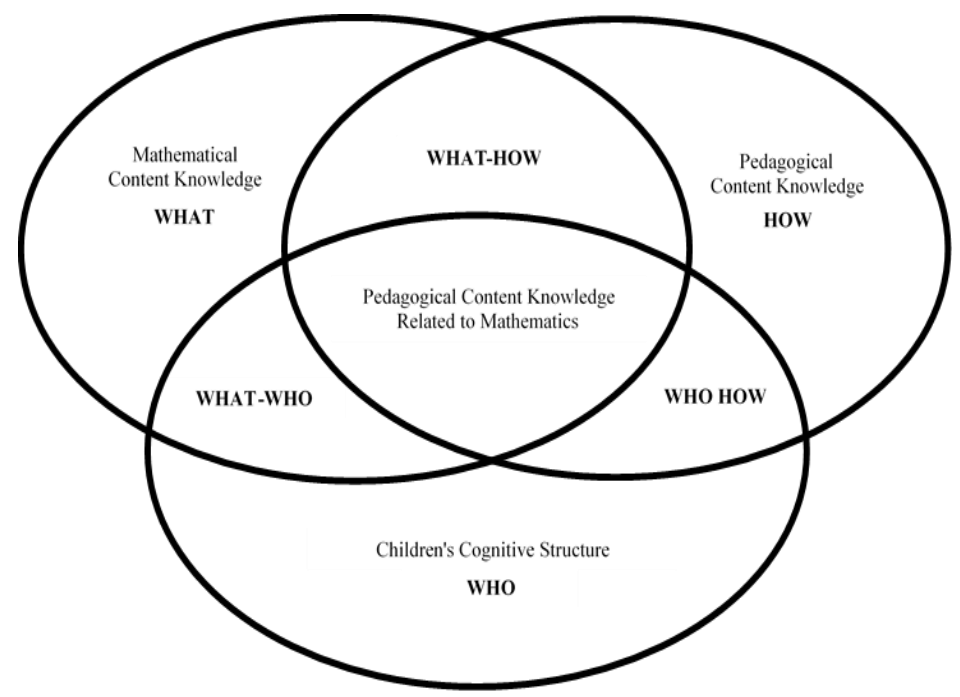

Figure 1. Pedagogical Content Knowledge Related to Mathematics (as revised by McCray, 2008)

McCray (2008) defined pedagogical content knowledge regarding mathematics as a junction point of three questions in mathematics education; Who will teach?, What to teach?, and How to teach? Teacher's pedagogical content knowledge, content knowledge and teaching ability 
are of paramount importance in effective learning and success in children (Jang, 2013; Zhang, 2015). The basis of mathematics education begins with an understanding of mathematical knowledge (Zhang, 2015).

Teachers with pedagogical mathematics concept knowledge know which concepts are the most basic and the best analogies that can gain help conceptual understanding; can enter events with new ideas in accordance with the interests of children, and ensure children use mathematics and mathematical language by asking children the right questions (McCray, 2008). The language used by teachers in the classroom should be founded upon improving the mathematical thinking of children. Guidelines for teachers in terms of mathematics contents such as numbers, spatial relationships, and operations should help children to use mathematics (Clements \& Sarama, 2014; McGrath, 2010). Teachers should provide support to enable children to develop a positive attitude towards mathematics by taking full account of mathematics education and preparing appropriate programs in this regard (Copley, 2010; Dağlığlu, Genç, \& Dağl1, 2017).

Previous studies show that teachers' attitudes, pedagogical field knowledge and beliefs affect children's mathematical ability, that the methods and techniques used by teachers affect children's ability in this field, and that teachers are lacking in mathematics education and in recognizing children's abilities (Chace Pierro, 2015; Cox, 2011; Erdoğan, 2006; Güven, 1998; Hacısalihoğlu Karadeniz, 2011; Kilday, 2010). From analyzing the relevant literature, a few studies have been specifically focused on preschool teachers' pedagogical content knowledge regarding mathematics (Cox, 2011; Kilday, 2010; McCray, 2008; Platas, 2008). However, studies that have been conducted in Turkey usually focus on preschool teachers' attitudes, beliefs and self-efficacy towards mathematics education (Çelik, 2017; Güven, Karataş, Öztürk, Arslan, \& Gürsoy, 2013; Karakuş, Akman, \& Ergene, 2018; Koç, Sak, \& Kayri, 2015; Şeker \& Alisinanoğlu, 2015); whereas only two studies considered pedagogical content knowledge regarding mathematics (Aksu \& Kul, 2017; Parpucu \& Erdoğan, 2017).

The current research was planned in order to develop a measurement tool for determining preschool teachers' pedagogical field knowledge of mathematics in order to address a gap in this field.

\section{METHOD}

This section includes information related to the working group, the data collection tool, and the development process of the scale.

\subsection{Working Group}

The participants of the study consisted of 300 teachers working in formal independent kindergartens and nursery classes of primary/secondary schools under the Turkish Ministry of National Education in Kahramanmaraş Province, Turkey; specifically, the districts of Dulkadiroğlu and Onikişubat. Of the participant teachers, 150 were selected for the preapplication and 150 for the main application.

While determining the size of the group to conduct factor analysis in the preliminary application, the researchers proposed different approaches; some argued that there should be twice the number of items (Büyüköztürk, Kılıç-Çakmak, Akgün, Karadeniz, \& Demirel, 2008), some four times the number of items (MacCallum, Widaman, Preacher, \& Hong, 2001), and others suggested 10 times (Nunnally, 1978). In addition, for exploratory factor analysis, KaiserMeyer-Olkin Test is expected to be greater than .50 and Bartlett test should be statistically significant (Büyüköztürk, 2010). In this regard, the decision was made to conduct an application with 150 teachers as the pre-application stage. Table 1 presents the demographic information regarding the participants. 
Table 1. Participants' Demographic Information

\begin{tabular}{|c|c|c|c|c|c|}
\hline \multirow{2}{*}{\multicolumn{2}{|c|}{ Demographic Information }} & \multicolumn{2}{|c|}{ Pre-application } & \multicolumn{2}{|c|}{ Main Application } \\
\hline & & \multirow{2}{*}{$\begin{array}{c}\text { Frequency } \\
130\end{array}$} & \multirow{2}{*}{$\begin{array}{c}\text { Percentage } \\
86.7\end{array}$} & \multirow{2}{*}{$\begin{array}{c}\text { Frequency } \\
150\end{array}$} & \multirow{2}{*}{$\begin{array}{c}\text { Percentage } \\
100.0\end{array}$} \\
\hline Gender & Female & & & & \\
\hline & Male & 20 & 13.3 & - & - \\
\hline \multirow{5}{*}{ Age (years) } & Less than 20 & 40 & 26.7 & 14 & 9.3 \\
\hline & $21-25$ & 47 & 31.3 & 42 & 28.0 \\
\hline & $26-30$ & 45 & 30.0 & 60 & 40.0 \\
\hline & $31-35$ & 18 & 12.0 & 33 & 22.0 \\
\hline & 36 or over & - & - & 1 & 0.7 \\
\hline \multirow{6}{*}{ Graduation } & High School / Girls' Vocational High School & - & - & - & - \\
\hline & $\begin{array}{ll}\text { Associate Degree } & \begin{array}{l}\text { Child Development } \\
\text { Vocational School }\end{array} \\
\end{array}$ & 23 & 15.3 & 8 & 5.3 \\
\hline & Preschool Teacher & 81 & 54.0 & 99 & 66.0 \\
\hline & $\begin{array}{ll}\text { Undergraduate } & \text { Child Development }\end{array}$ & 41 & 27.3 & 34 & 22.7 \\
\hline & Postgraduate & 5 & 3.4 & 6 & 4.0 \\
\hline & Other & - & - & 3 & 2.0 \\
\hline \multirow{6}{*}{ Seniority (years) } & Less than 1 year & 25 & 16.7 & 4 & 2.7 \\
\hline & $1-5$ years & 36 & 24.0 & 23 & 15.3 \\
\hline & $6-10$ years & 59 & 39.3 & 64 & 42.7 \\
\hline & $11-15$ years & 18 & 12.0 & 37 & 24.6 \\
\hline & $16-20$ years & 8 & 5.3 & 13 & 8.7 \\
\hline & 21 years or more & 4 & 2.7 & 9 & 6.0 \\
\hline \multirow{3}{*}{ Institution } & Independent kindergarten & 106 & 70.7 & 90 & 60.0 \\
\hline & Primary school & 27 & 18.0 & 50 & 33.3 \\
\hline & Secondary school & 17 & 11.3 & 10 & 6.7 \\
\hline \multirow{4}{*}{$\begin{array}{l}\text { Number of } \\
\text { Children } \\
\text { (per class) }\end{array}$} & $5-10$ & 2 & 1.3 & 5 & 3.3 \\
\hline & $11-15$ & 12 & 8.0 & 14 & 9.3 \\
\hline & $16-20$ & 74 & 49.3 & 67 & 44.7 \\
\hline & 21 or more & 62 & 41.3 & 64 & 42.7 \\
\hline \multirow{3}{*}{ Age of Children } & $36-53$ months & 15 & 10.0 & - & - \\
\hline & 54-60 months & 70 & 46.7 & 308 & 51.3 \\
\hline & 61-66 months & 65 & 43.3 & 292 & 48.7 \\
\hline \multirow{5}{*}{$\begin{array}{l}\text { Mathematical } \\
\text { Activities }\end{array}$} & Never & - & - & - & - \\
\hline & One time per $2-3$ weeks & - & - & 3 & 2.0 \\
\hline & Twice a week & 41 & 27.3 & 38 & 25.3 \\
\hline & Three to four times a week & 86 & 57.3 & 73 & 48.7 \\
\hline & Daily & 23 & 15.4 & 36 & 24.0 \\
\hline
\end{tabular}

Table 1 shows that $86.7 \%(n=130)$ of the participant teachers were female, whilst $13.3 \%$ $(n=20)$ were male for the pre-application stage; whereas, all participants were female for the main application. In the pre-application, $10 \%(n=15)$ of the teachers were working with children aged between 36 and 53 months, 46.7\% $(n=70)$ between 54 and 60 months, and 43.3\% $(n=65)$ between 61 and 66 months. In the main application, 51.3\% $(n=308)$ of the teachers were working with children aged between 54 and 60 months, whilst the other $49.7 \%$ $(n=292)$ were working with children aged between 61 and 66 months.

\subsection{Data Collection Tool}

The research data was collected through a "Teacher Information Form" and a developed "Preschool Teachers' Pedagogical Content Knowledge Scale regarding Mathematics 
(PTPCKSM)" that included five case studies. The Teacher Information Form was used in order to record the teachers' gender, age, type of graduation school, their seniority, type of institution where they were assigned, the number of children in each class, the age group of the children in their class, and the availability of a mathematics center in class.

The PTPCKSM was developed in order to identify teachers' awareness towards mathematical content and the processes involved in language used by children. In this section, five case studies were designed based on children's dialogues including different mathematical contexts and processes from the expressions used by children during play. A separate marking form was created for each case study and teachers were requested to mark the mathematical contents and processes they identified in accordance with the form. Based on the NCTM (2000) standards, the case studies of the PTPCKSM included "counting, geometry, spatial perception, part-whole relationships, matching, classification/grouping, comparison, sorting, measurement, operation, pattern, and graphics" as the mathematics contents, and "communication, association, reasoning and proof, problem solving and representation/symbolization" as the mathematical processes. Each case study consisted of seven statements/items.

During the scale's development process, first the existing literature was reviewed. The contents and processes involved in mathematics education during the preschool period in Turkey and elsewhere were examined, and the sub-dimensions for the PTPCKSM were formed after determining the problem statement based on the aforementioned content. The scale known as "Knowledge of Mathematical Development" that was developed by Platas (2008) for the purpose of measuring teachers' knowledge on the development of mathematical concepts in children was taken as the basis for the current study. Along with the necessary permissions in the ongoing process, the "Preschool Mathematics-Pedagogical Concept Information Interview Form" that was developed by McCray and Chen (2008) was also taken into consideration.

Two of the five case studies in the PTPCKSM were prepared based on the Preschool Mathematics-Pedagogical Concept Information Interview Form; with the other three case studies formed by the researcher. The case studies were designed based on a straight line approach, from simple to complex. Each case study contained different yet simple images in order to add clarity to the case studies. With examination of the content and process standards developed by the National Association for the Education of Young Children in America and NCTM, as well as the involvement in the development process of mathematical concepts in children, significant attention was paid to the inclusion of these standards in case study. Within the scale development process, three different scale drafts were prepared in the form and coding dimension, and each draft was applied to three different preschool teachers. The scale was then finalized by testing the clarity of the scale with various applications.

The expert opinion of seven specialists in mathematics and preschool education, who were also faculty members at different universities, were obtained in the preparation of the scale. In addition, a measurement and evaluation expert plus and two Turkish linguists were employed to examine the scale in terms of the language clarity and application of the items. The scale was considered ready for the pre-application stage after having taken a total of nine expert opinions. In the PTPCKSM, spelling errors and incoherencies were corrected so as to increase the scale's clarity along with the expert opinion. In order that the data could be grouped and the correct comparisons made, International Standard Classification of Education (ISCED) categories (Türkiye İstatistik Kurumu Başkanlığı [Turkish Statistical Institute], 2012) were employed. In addition, categories (as mathematics contents and mathematical processes) were created for some related items.

One of the case studies is presented in Figure 2, and the scoring table in the marking form created for the teachers to record their answers is shown in Figure 3. In each case study, first the image and the text were taken as a whole; then, in the marking section, each sentence (item) 
was taken separately by dividing each sentence (item) in the case study. Here, the teachers were expected to see the whole, then the application was made by dividing the text into sentences in order to be more easily recognize the details in the text.

Preschool Teachers' Pedagogical Content Knowledge Scale related to the Mathematics

CASE STUDY 1)

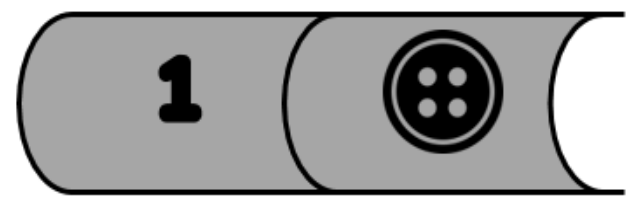

- Gül and Naz play in the mathematics center. In the case study, numbers between 1 and 10 and the use of puzzle-like number and object matching cards containing the same number of objects were explained.

** Gül says "Let's play with cards in the drawer."

** Naz says "There are 6 matching cards here. Let's put these on the table." and puts the cards on the table.

** Gül takes the number 1 and says "This is 1 . I have to put the card with 1 button next to the number $1 . "$

** Naz says "This is 2 . Let's put the card with 2 buttons next to the number $2 . "$

** Gül says "This is 3 " and brings the card with 3 buttons next to the number.

** Naz says "1, 2 and $3 "$ and counts the numbers in order

** Gül counts the buttons and says "All correct" and they continue their games.

Figure 2. PTPCKSM Case Study Form

CASE STUDY 1 SCORING TABLE

In the case study above, you need to examine the sentences in dialogues among children during the game and then you need to associate every sentence with mathematical content and/or process areas at the side column. Put an "X" to the mathematics content that you think is in the sentence.

\begin{tabular}{|c|c|c|c|c|c|c|c|c|c|c|c|c|c|c|c|c|c|c|c|}
\hline & \multirow[b]{2}{*}{ EXAMPLE IN THE GAME } & \multicolumn{13}{|c|}{ MATHEMATICAL CONTENT } & \multicolumn{5}{|c|}{ MATHEMATICAL PROCESS } \\
\hline & & 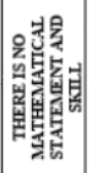 & $\begin{array}{l}\text { 息 } \\
\text { 足 }\end{array}$ & 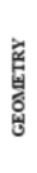 & 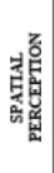 & 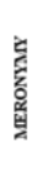 & 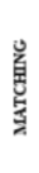 & 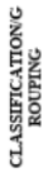 & 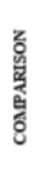 & 咅 & $\begin{array}{l}\text { 点 } \\
\text { 䚁 } \\
\text { 点 } \\
\text { 息 }\end{array}$ & 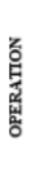 & 䓛 & 蔓 & 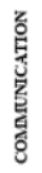 & 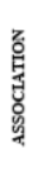 & 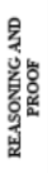 & 氪 & 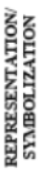 \\
\hline 1 & $\begin{array}{l}\text { Gul says "Let's play with cards in the } \\
\text { drawer." }\end{array}$ & & & & & & & & & & & & & & & & & & \\
\hline 2 & $\begin{array}{l}\text { Naz says "There are } 6 \text { matching cards } \\
\text { here. Let's put these on the table." and } \\
\text { puts the cards on the table. }\end{array}$ & & & & & & & & & & & & & & & & & & \\
\hline 3 & $\begin{array}{l}\text { Gül takes the number } 1 \text { and says "This is } \\
1 \text {. I have to put the card with } 1 \text { button } \\
\text { next to the number } 1 . "\end{array}$ & & & & & & & & & & & & & & & & & & \\
\hline 4 & $\begin{array}{l}\text { Naz says "This is } 2 \text {. Let's put the card } \\
\text { with } 2 \text { buttons next to the number } 2 . "\end{array}$ & & & & & & & & & & & & & & & & & & \\
\hline 5 & $\begin{array}{l}\text { Gül says "This is } 3 \text { " and brings the card } \\
\text { with } 3 \text { buttons next to the number. }\end{array}$ & & & & & & & & & & & & & & & & & & \\
\hline 6 & $\begin{array}{l}\text { Naz says "1,2 and } 3 " \text { and counts the } \\
\text { numbers in order. }\end{array}$ & & & & & & & & & & & & & & & & & & \\
\hline 7 & $\begin{array}{l}\text { Gül counts the buttons and says "All } \\
\text { correct" and they continue their games. }\end{array}$ & & & & & & & & & & & & & & & & & & \\
\hline
\end{tabular}

Figure 3. PTPCKSM Scoring Table 
As can be seen in the case study shown in Figure 2 and Figure 3, the PTPCKSM contains one or more mathematical contents/processes within each sentence. Each item was rated as 1 point in the scale; therefore, the whole case study was calculated as a total of 7 points, with each case study consisting of seven items. The pedagogical content knowledge of the teachers with the highest total score were therefore expected to be considered as high.

\subsection{Data Collection Process}

In both the pre-application and the main application, educational institutions were visited by the researcher where the necessary permissions had been received. The school principals were informed about the study first, and then interviews were subsequently held with each participant teacher. The scale was introduced to the teachers in person by the researcher, and any necessary corrections to the scale were applied together. The teachers requested additional time in order to better complete the scale. The forms were delivered to the teachers by the researcher, and later retrieved according to pre-specified dates.

\subsection{Data Analysis}

IBM's SPSS 22 statistical package and the Mplus 7.4 program were used in order to calculate the reliability and validity of the developed scale. Cronbach Alpha coefficient was used to test the reliability of the scale, and then item difficulty index values and item discrimination coefficients were calculated separately for each item. In order to calculate the validity of the scale, the content and construct validity were examined; both exploratory and confirmatory factor analyses were performed for this purpose. Kaiser-Meyer-Olkin Test and Bartlett Tests were performed in exploratory factor analysis (EFA); whilst CFI, TLI, RMSEA and SRMR values were calculated for the scale's confirmatory factor analysis (CFA).

Before scoring, each mathematics content and process in the scale was alphabetically coded as a, b, c, d, e, f.......p. Table 2 shows the codes corresponding to the mathematical contents and processes.

Table 2. PTPCKSM Content/Process Coding Values

\begin{tabular}{lc}
\hline Mathematics Content/Process & Coding Value \\
\hline There is No Mathematical Statement and Skill & $\mathrm{a}$ \\
\hline Counting & $\mathrm{b}$ \\
\hline Geometry & $\mathrm{c}$ \\
\hline Spatial Perception & $\mathrm{d}$ \\
\hline Part-Whole Relationships & $\mathrm{e}$ \\
\hline Matching & $\mathrm{f}$ \\
\hline Classification/Grouping & $\mathrm{g}$ \\
\hline Comparison & $\mathrm{h}$ \\
\hline Measurement & $\mathrm{i}$ \\
\hline Operation & $\mathrm{j}$ \\
\hline Pattern & $\mathrm{k}$ \\
\hline Graphic & $\mathrm{l}$ \\
\hline Communication & $\mathrm{m}$ \\
\hline Association & $\mathrm{n}$ \\
\hline Reasoning and Proof & $\mathrm{o}$ \\
\hline Problem Solving & $\ddot{\mathrm{d}}$ \\
\hline Representation/Symbolization & $\mathrm{p}$ \\
\hline
\end{tabular}


In the scoring method, each item was awarded equal points (equal scoring) (Frary, 1989; Masters, 1988).

Each item is worth 1 point, and in scoring the item total is divided by the number of answers required for its content/process. For example, the per code value of Item 1, in which the correct answer was " $\mathrm{d}$ and $\mathrm{m}$," is calculated as $1 / 2(0.50)$; and the per code value of Item 2 , in which the correct answer was " $b, d$ and $m$," is calculated as $1 / 3(0.33)$.

Any incorrect answer results in 1 point deducted from the total score. For example, a response of " $\mathrm{b}, \mathrm{d}$ and $\mathrm{n}$ " for Item 3 includes one correct and two incorrect answers; therefore, the score corresponds to 2 - 1 correct answer is calculated as $1 / 3(0.33)$ points because there are three correct answers in this question.

\section{RESULTS}

The research findings related to the preschool teachers' pedagogical content knowledge on mathematics are reported in the following figures and tables.

\subsection{Results for Pre-Application}

\subsubsection{Reliability}

Each case study in the PTPCKSM and the reliability coefficient calculation for the whole scale are shown in Table 3 . Table 3 shows that the reliability coefficient for each case study was found to be more than .70, and that the reliability coefficient levels of the whole scale and each case study were therefore considered "high" (Büyüköztürk, 2010). The reliability coefficients of the case studies were identified as varying from .94 to .96; and the reliability coefficient for the whole scale was found to be .95 .

Table 3. Reliability Coefficients of PTPCKSM

\begin{tabular}{lcc}
\hline Case Study & Number of Items & Reliability coefficient \\
\hline Case Study 1 & 7 & .95 \\
\hline Case Study 2 & 7 & .94 \\
\hline Case Study 3 & 7 & .96 \\
\hline Case Study 4 & 7 & .94 \\
\hline Case Study 5 & 7 & .96 \\
\hline Whole Scale & 35 & .95 \\
\hline
\end{tabular}

Item difficulty and discrimination indices for the items in each case study are presented as shown in Table 4.

Table 4. Item-level Statistics Related to PTPCKSM Case Studies

\begin{tabular}{lcccccccccc}
\hline \multirow{2}{*}{ Item } & \multicolumn{2}{c}{ Case Study 1 } & \multicolumn{2}{c}{ Case Study 2 } & \multicolumn{2}{c}{ Case Study 3 } & \multicolumn{2}{c}{ Case Study 4 } & \multicolumn{2}{c}{ Case Study 5 } \\
\cline { 2 - 10 } & $p$ & $r$ & $p$ & $r$ & $p$ & $r$ & $p$ & $r$ & $p$ & $r$ \\
\hline Item 1 & .49 & .69 & .70 & .57 & .56 & .79 & .53 & .87 & .51 & .90 \\
Item 2 & .51 & .85 & .45 & .91 & .38 & .93 & .50 & .71 & .38 & .90 \\
Item 3 & .42 & .95 & .37 & .92 & .35 & .94 & .36 & .44 & .43 & .92 \\
Item 4 & .38 & .88 & .46 & .84 & .40 & .92 & .38 & .91 & .57 & .81 \\
Item 5 & .40 & .93 & .38 & .86 & .39 & .91 & .45 & .93 & .45 & .90 \\
Item 6 & .53 & .78 & .39 & .90 & .47 & .85 & .44 & .91 & .34 & .72 \\
Item 7 & .42 & .89 & .36 & .91 & .37 & .78 & .47 & .87 & .45 & .88 \\
\hline
\end{tabular}


Table 4 shows the item difficulty index values $(p)$ and the item discrimination index values $(r)$ of the items in Case Study 1. Basol (2015) classified item difficulty as "extremely easy" ( $p=.85$ to 1.00$)$, "easy" ( $p=.61$ to .84$)$, "medium" ( $p=.40$ to .60$)$, "difficult" ( $p=.16$ to .39 ), and "extremely difficult" ( $p=.00$ to .15$)$. For Case Study 1 , the item difficulties differed from .38 to .53 and were therefore classed as either medium $(p=.49, .51, .42, .40, .53, .42)$ or difficult $(p=.38)$. The item discrimination index values in Case Study 1 varied between .69 and .95 .

The item difficulty index values of Case Study 2, varied between .36 and .70 , with item difficulties easy $(p=.70)$, medium $(p=.47, .40)$ or difficult $(p=.39, .38, .37, .35)$. The item discrimination index values for Case Study 2 varied between .57 and .92 .

The item difficulty index values of Case Study 3 varied between .35 and .56 , with item difficulties either medium $(p=.56, .46, .45)$ or difficult $(p=.39, .38, .37, .36)$. The item discrimination index values for Case Study 3 varied between .78 and .94.

The item difficulty index values of Case Study 4 varied between .36 and .53 , with item difficulties either medium $(p=.53, .50, .47, .45, .44)$ or difficult $(p=.38, .36)$. The item discrimination index values for Case Study 4 varied between .44 and .93 .

The item difficulty index values of Case Study 5 varied between .34 and .57 , with item difficulties either medium $(p=.53, .51, .45, .43)$ or difficult $(p=.38, .34)$. The item discrimination index values for Case Study 5 varied between .72 and .90 .

The results indicated that the questions were classified as either difficult, medium or easy, and that the item discrimination index values were found to have more than .30 of variance explained by the scale (Thorndike, 2005).

\subsubsection{Validity}

The content and the construct validity indices were examined through exploratory and confirmatory factor analyses.

\subsubsection{Content Validity}

The opinion of seven experts was sought in order to assess the content validity of the PTPCKSM. All of the items were accepted by the experts.

The content validity rate for each item was determined based on the evaluation of the expert opinion. Afterwards, the content validity index value was determined by taking the average of the calculated rates. The index value for each item was then used by the experts to determine whether or not the item was deemed necessary (Büyüköztürk, 2010; Yurdugül, 2005).

The content validity index value was calculated for the eligibility level of the scale items as a whole. With seven experts, scales with a content validity index value of more than .99 can assure scope validity (Yurduguil, 2005). From calculation of the content validity index values for the PTPCKSM, the eligibility level of the items in terms of their intended purpose and the level of the children was calculated as " +1 ." This value shows that all items in the PTPCKSM were deemed to be necessary, and that the scale's content validity was assured as a whole.

\subsubsection{Construct Validity}

Exploratory factor analysis (EFA) of the scale was conducted in order to demonstrate the construct validity of the PTPCKSM at the pre-application stage. Both the Kaiser-Meyer-Olkin and Bartlett tests were performed to understand whether or not the scale was appropriate for factor analysis. For ensuring factor analysis of a scale, the Kaiser-Meyer-Olkin result should be .50 or above, and the Bartlett Sphericity result should be statistically significant $(p<.01)$ (Büyüköztürk, 2010). 
The analysis results showed that the Kaiser-Meyer-Olkin result for the PTPCKSM was .97 and that the Bartlett sphericity test $(p<.01)$ was statistically significant. This result shows that factor analysis may be performed on the scale. Upon examining the eigenvalue for both methods, there are two factors that score as more than 1; with the first factor being 25.58 and the second factor 1.86. These two factors were found to account for $78.41 \%$ of the total variance in the scale, with $73.11 \%$ explained by Factor 1 and $5.30 \%$ by Factor 2 . Considering the eigenvalue and the explained variance, Factor 1 was found to be about 14 times more dominant than Factor 2. This result therefore signified that the scale has a single factor structure. Figure 4 presents a scatter plot graph of the scale.

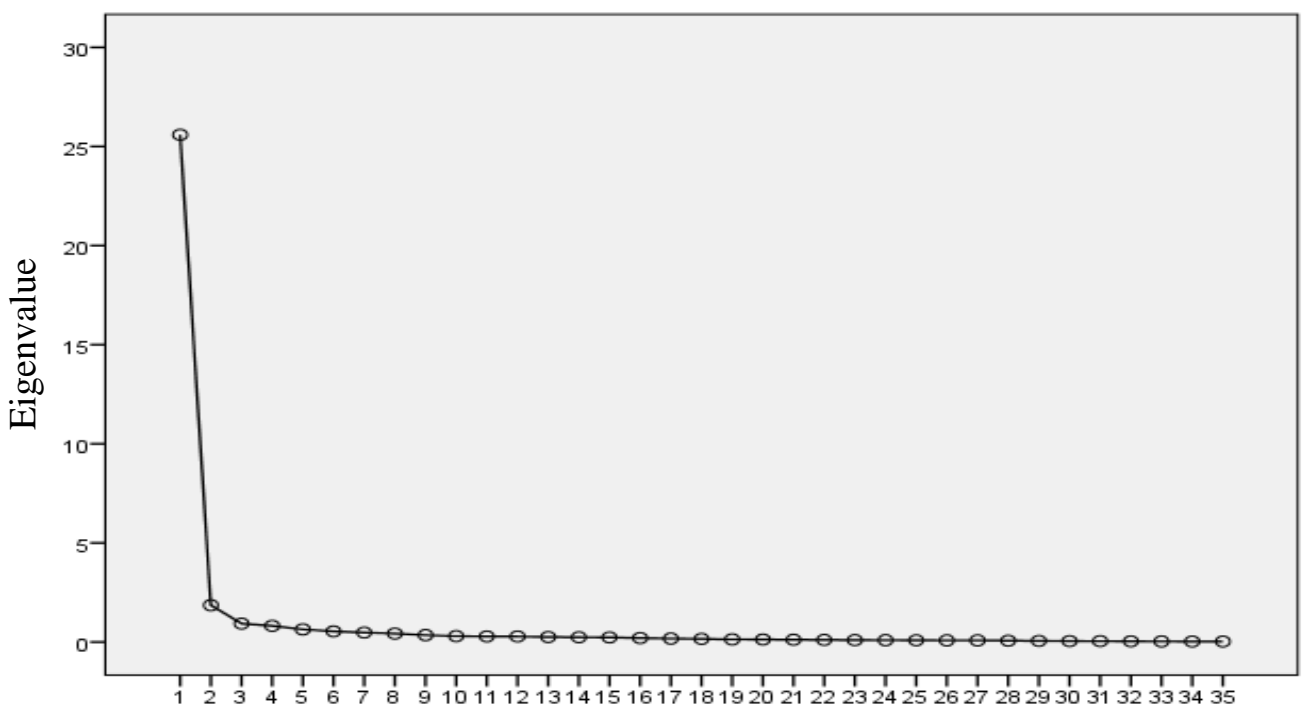

Number of Components

Figure 4. Scatter Plot Graph

Table 5. Factor Load Values as a Result of Principal Component Analysis of PTPCKSM

\begin{tabular}{|c|c|c|c|c|c|}
\hline \multirow{2}{*}{ Item } & \multicolumn{2}{|c|}{ Factor Loads } & \multirow{2}{*}{ Item } & \multicolumn{2}{|c|}{ Factor Loads } \\
\hline & Factor 1 & Factor 2 & & Factor 1 & Factor 2 \\
\hline O1_3 & .95 & & O1_7 & .89 & \\
\hline O3_3 & .94 & & O5_7 & .89 & \\
\hline O4_5 & .93 & & O1_4 & .88 & \\
\hline O3_2 & .93 & & O4_7 & .87 & \\
\hline O1_5 & .93 & & O4_1 & .87 & \\
\hline O2_3 & .93 & & O2_5 & .87 & \\
\hline O3_4 & .93 & & O3_6 & .85 & \\
\hline O5_3 & .92 & & O1_2 & .85 & \\
\hline O3_5 & .92 & & O2_4 & .84 & \\
\hline O4_4 & .91 & & O5_4 & .81 & \\
\hline O2_2 & .91 & & O1_6 & .78 & \\
\hline O2_7 & .91 & & O3_1 & .78 & \\
\hline O5_2 & .91 & & O3_7 & .77 & \\
\hline O4_6 & .91 & & O5_6 & .72 & \\
\hline O5_1 & .90 & & O4_2 & .69 & .62 \\
\hline O2_6 & .90 & & O1_1 & .69 & \\
\hline O5_5 & .90 & & O2_1 & .55 & \\
\hline & & & O4_3 & .42 & .81 \\
\hline
\end{tabular}


When the factor loadings of each item were examined in the next stage, no item was found with a factor load value of less than .30, and therefore no items were removed from the scale. According to Table 5, only two factors were identified as being linked at the same time, such as Case Study 4, Item 2 and Case Study 4, Item 3. As the difference between the Factor 1 loading (.42) and Factor 2 loading (.81) of Item O4_3 was greater than .10, it was assumed that this problem was only due to Factor 2. As the difference between the Factor 1 loading (.69) and Factor 2 loading (.62) of Item O4_2 (Case Study 4, Item 2) was less than .10, it was considered that this item should be removed from the scale. However, since this item was thought to contribute to the scale contextually (content validity), it was decided not to remove the item from the scale.

\subsection{Findings for the Main Application}

As in the pre-application, the reliability coefficient was examined and the construct validity was also tested in the main application. However, the construct validity was tested by confirmatory factor analysis (CFA) in the main application.

\subsubsection{Reliability}

First, as shown in Table 6, the reliability coefficients of the scale were calculated at both the individual case study level and for the whole scale.

Table 6. Reliability Coefficients of PTPCKSM

\begin{tabular}{lcc}
\hline Case Study & Number of Items & Reliability coefficient \\
\hline Case Study 1 & 7 & .91 \\
\hline Case Study 2 & 7 & .73 \\
\hline Case Study 3 & 7 & .82 \\
\hline Case Study 4 & 7 & .81 \\
\hline Case Study 5 & 7 & .86 \\
\hline Whole Scale & 35 & .96 \\
\hline
\end{tabular}

According to the findings presented in Table 6, the reliability coefficient for each of the individual case studies was found to be more than .70, and that the reliability coefficient levels of the scale as a whole and each case study were considered to be high (Büyüköztürk, 2010). The reliability coefficients of the individual case studies varied from .73 to .91; and the reliability coefficient of the whole scale was found to be .96 .

\subsubsection{Validity}

In order to test the construct validity of the scale at the next stage, confirmatory factor analysis (CFA) was performed using the MPlus 7.4 program, and the model produced by this analysis is shown as Figure 5. When the goodness of fit indices of the model, it was found that the CFI and TLI values were greater than .90, and that the RMSEA and SRMR values were less than .08 . These results showed that the model was at an acceptable level (Kline, 2016). The $\chi^{2} / S D$ value was calculated to be less than the accepted value of $4\left(\chi^{2}(547,150)=821.76 ; \mathrm{CFI}=.91\right.$; $\mathrm{TLI}=.91$; RMSEA $=.06$; SRMR $=.06$ ). These results support that the scale has acceptable construct validity (Kline, 2016). As a result, both the reliability and validity analyses results for the main application revealed the PTPCKSM to be a suitable measurement tool. 


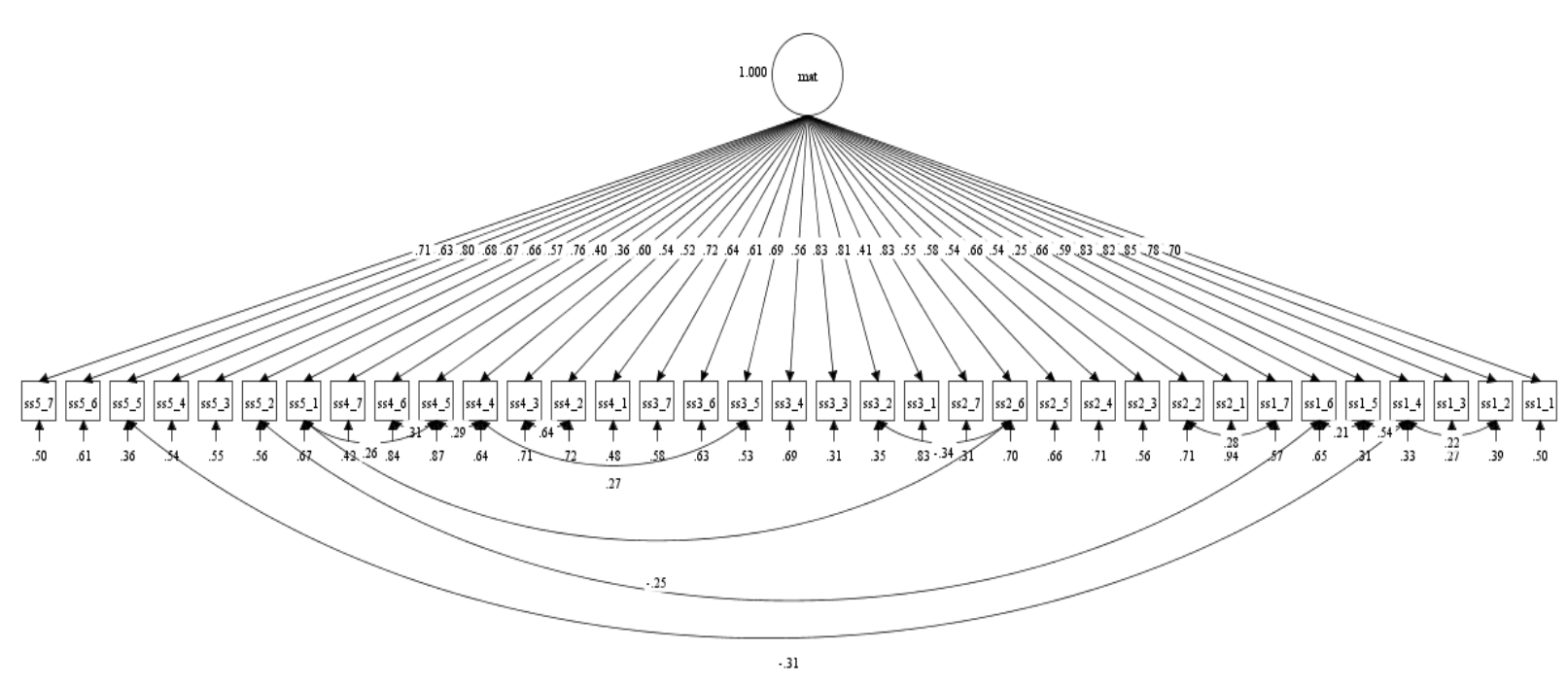

Figure 5. PTPCKSM Confirmatory Factor Analysis Model

\section{DISCUSSION and CONCLUSION}

Considering that mathematics is intertwined in our life skills and that the skills and processes related to mathematics develop in children during their early years, the importance of preschool teachers' pedagogical knowledge about mathematics is significant. This position illustrates the necessity for different measurement tools to assess preschool teachers' pedagogical content knowledge. Therefore, the current study was conducted in order to develop a new tool known as the Preschool Teachers' Pedagogical Content Knowledge Regarding Mathematics Scale; as well as to perform validity and reliability studies on the developed scale.

The participants of the study were 300 preschool teachers working in formal independent kindergartens and in nursery classes of primary/secondary schools under the Turkish Ministry of National Education within the Kahramanmaraş Province of Turkey.

A Teacher Information Form and the Preschool Teachers' Pedagogical Content Knowledge Regarding Mathematics Scale, which were both developed by the researcher, were employed as the data collection tools in this study. A pre-application study was conducted in order to determine the clarity and responsiveness of the PTPCKSM scale items, and all of the items were identified to have the necessary level of clarity.

For a valid scale, the problem should be well-defined, and statistically accepted values for both validity and reliability should be assured during preparation of the scale items (Büyüköztürk, 2005). The reliability coefficients of the PTPCKSM were calculated. The findings presented in Table 1 reveal that the reliability coefficient of each case study in the PTPCKSM to be more than .70, and that the reliability coefficient of the whole scale was .95 which indicated the scale to be reliable (Büyüköztürk, 2010). The item difficulty index value $(p)$ and the item discrimination index value $(r)$ were calculated separately for each item in each case study of the scale (see Table 2). When the item difficulty index values of the case studies were examined, they were found to vary between easy, medium and difficult; whilst the item discrimination index values were found to be higher than .30 .

In addition to reliability, another requirement for determination of the scale is validity (Karasar, 2012). Therefore, explanatory and confirmatory factor analyzes indicating the construct validity as well as the content validity analysis were performed.

Seven expert opinions were consulted to determine the content validity of PTPCKSM. All of the items were welcomed by the experts. Content validity index was examined with the expert opinions; as a result of the calculation of the content validity index values of PTPCKSM, content validity index for eligibility level of the items in terms of the purpose and level of 
children was calculated as " +1 ". This value showed that all the items in the scale were necessary and the scale guaranteed content validity as a whole.

Kaiser-Meyer-Olkin Test result for PTPCKSM was found to be .97 and the Bartlett sphericity test $(\mathrm{p}<0.01)$ was statistically significant. This result showed that factor analysis can be performed on the scale. As a result of the factor analysis, Case Study 4 Item 2 and Case Study 4 Item 3 including contents and processes such as counting, geometry, classification/grouping and communication were linked two factors at the same time; as the difference between the two factors of the Case Study 4 Item 3 was greater than 0.10 , and that this problem may be only due to factor 2. The difference between the two factors of the Case Study 4 Item 2 was found less than 0.10 . However, since this item was assumed to contribute to the scale contextually (content validity) and the removal of the item would harm the integrity of the scale; this item was not removed from the scale.

In the next stage, confirmatory factor analysis was performed through use of the MPlus 7.4 program to test the construct validity of the scale (Figure 3). When model fit indexes were examined, CFI and TLI values were identified to be more than 0.90 and 0.90 and RMSEA and SRMR values were less than 0.08 and the model was in an acceptable level in terms of its construct validity (Kline, 2016). It was also found that the $\chi^{2} / S D$ value was less than the accepted value of $4 \quad\left(\chi^{2}(487.152)=972.22 ; \quad\right.$ CFI $=.94 ; \quad$ TLI $=.93 ; \quad$ RMSEA $=.07$; SRMR =.04). According to these applications, it was revealed that the Preschool Teachers' Pedagogical Content Knowledge Related to the Mathematics Scale is a suitable measuring tool including five case studies and 35 items based on the assessment of preschool mathematical contents and processes.

Mathematics is a hierarchical field, and basic mathematical skills and concepts are acquired during the preschool period. Therefore, children's acquirements within this scope come to the fore especially during their early childhood. The relevant literature revealed that the attitudes, approaches, beliefs and pedagogical content knowledge of preschool teachers related to mathematics are primary factors affecting children's acquirements in this field (Chace Pierro, 2015; Cox, 2011; Erdoğan, 2006; Güven, 1998; Hacısalihoğlu Karadeniz, 2011; Kilday 2010). However, considering the academic studies carried out with regards to preschool teachers' pedagogical content knowledge related to mathematics, only a few studies have been conducted on this subject in Turkey (Aksu \& Kul, 2017; Parpucu \& Erdoğan, 2017).

When studies on the pedagogical content knowledge related to mathematics for teachers working in primary education or upper education levels were examined, the knowledge level of teachers were shown to be low, and that major changes can be seen in teachers' thoughts and beliefs on mathematics education and teaching after having received supportive training in this area (Even \& Tirosh, 1995; Gökkurt \& Soylu, 2016; Nicol \& Crespo, 2006; Tanışl1, 2013). Under these circumstances, the scale developed in the current study is expected to contribute to the related field. Based upon the study's findings, it is recommended that the validity and reliability of the developed scale be repeated for teachers working in different regions and provinces across Turkey. The scale may also be applied to teachers working with different age groups, in areas differentiated by socioeconomic level, and in different preschool education institutions. Relations between teachers' pedagogical content knowledge regarding mathematics and variables such as children's mathematical ability, levels of children's love for mathematics, and their attitudes towards mathematics may be analyzed and in-depth examinations conducted in order to reveal how teachers' content knowledge related to mathematics affects the development of children's mathematical concepts.

\section{Acknowledgement}

This paper is part of a doctoral dissertation of the corresponding author. 


\section{ORCID}

Hatice Dağl1 (D) https://orcid.org/0000-0002-0788-0413

H. Elif Dağlıoğlu (D) https://orcid.org/0000-0002-7420-815X

E. Hasan Atalmış (iD https://orcid.org/0000-0001-9610-491X

\section{REFERENCES}

Aksu, Z., \& Kul, U. (2017). Turkish adaptation of the survey of pedagogical content knowledge in early childhood mathematics education. International Journal of Eurasia Social Sciences, 8(30), 1832-1848.

Anders, Y., Grosse, C., Rossbach, H., Ebert, S., \& Weinert, S. (2013). Preschool and primary school influences on the development of children's early numeracy skills between the ages of 3 and 7 years in Germany. School Effectiveness and School Improvement, 24(2), 195-211.

Anders, Y., \& Rossbach, H.G. (2015). Preschool teachers' sensitivity to mathematics in children's play: The influence of math-related school experiences, emotional attitudes, and pedagogical beliefs. Journal of Research in Childhood Early Education, 29(3), 305322.

Anthony, G., \& Walshaw, M. (2009). Mathematics education in the early years: Building bridges. Contemporary Issues in Early Childhood, 10(2), 107-121. doi: http://dx.doi.org/10.2304/ciec.2009.10.2.107

Arnas, Y. (2006). Okul öncesi dönemde matematik eğitimi [Mathematics education in preschool], Adana: Nobel.

Aunola, K., Leskinen, E., Lerkkanen, M.K., \& Nurmi, J.E. (2004). Developmental dynamics of math performance from preschool to grade 2. Journal of Educational Psychology, 96(4), 699-713.

Baranek, L. K. (1996). The effect of rewards and motivation on student achievement. Master's thesis. Grand Valley State University, MI.

Basol, G. (2015). Eğitimde ölçme ve değerlendirme [Measurement and evaluation in education], Ankara: Pegem.

Berhenge, A. L. (2013). Motivation, self-regulation, and learning in preschool. (Doctoral Dissertation). University of Michigan, USA.

Bulut, S., \& Tarım, K. (2006). Okul öncesi öğretmenlerinin matematik ve matematik öğretimine ilişkin alg1 ve tutumları [Perceptions and attitudes of preschool teachers about mathematics and mathematics teaching]. Çukurova Üniversitesi, Ĕgitim Fakültesi Dergisi, 2, 32-65.

Büyüköztürk, Ş. (2005). Anket geliştirme [Survey Development]. Türk Eğitim Bilimleri Dergisi, 3(2), 133-151.

Büyüköztürk, Ş. (2010). Sosyal bilimler için veri analizi el kitabı. istatistik, araştırma deseni SPSS uygulamalarl ve yorum. değerlendirme [Data analysis handbook for social sciences statistics, research design SPSS applications and interpretation], Ankara: Pegem Akademi.

Büyüköztürk, Ş., Kılıç-Çakmak, E., Akgün, Ö. E., Karadeniz, Ş., \& Demirel, F. (2008). Bilimsel Araştırma Yöntemleri (1st Ed.) [Scientific Research Methods], Ankara: Pegem.

Chace Pierro, R. (2015). Teachers' knowledge, beliefs, self-efficacy, and implementation of early childhood learning standards in science and math in prekindergarten and kindergarten. (Master's thesis). University of North Carolina, USA. Retrieved from https://libres.uncg.edu/ir/uncg/f/Pierro_uncg_0154M_11772.pdf

Claesens, A., \& Engel, M. (2013). How important is where you start? Early mathematics knowledge and later school success. Teachers College Record, 115(6), 1-29. 
Clements, D. H., \& Sarama, J. (2014). Learning and teaching early math: The Learning Trajectories Approach (2nd Ed.). New York, NY: Routledge.

Clements, D. H., Sarama, J., \& DiBiase, A.-M. (Eds.). (2004). Engaging young children in mathematics: Standards for early childhood mathematics education. Mahwah, NJ: Erlbaum.

Copley, J. V. (2010). The young child and mathematics (2nd Ed.). Washington DC: National Association for the Education of Young Children.

Cox, G. J. (2011). Preschool caregivers' mathematical anxiety: examining the relationships between mathematical anxiety, and knowledge and beliefs about mathematics for young children (Doctoral Dissertation). Texas Woman's University, Denton, TX.

Çelik, M. (2017). Okul öncesi öğretmenlerin erken matematik eğitimine ilişkin öz yeterliklerinin çeşitli değişkenler açısından incelenmesi [Pre-school teachers' self efficacy related to early maths education]. e-Kafkas Ĕ̆itim Araştırmaları Dergisi, 4(1), 1-10.

Çoban, A. (2002). Matematik dersinin ilköğretim programları ve liselere giriş sinavları açısından değerlendirilmesi [Evaluation of mathematics course in terms of primary education programs and high school entrance exams]. In Proceedings of the V. National Science and Mathematics Education Congress, Middle East Technical University, Ankara, Turkey. http://old.fedu.metu.edu.tr/ufbmek5/b_kitabi/PDF/Matematik/Bildiri/t2 19d.pdf

Dağl1, H., \& Dağlıoğlı, H. E. (2017). Preschool teachers' pedagogical content knowledge about mathematics. In I. Koleva \& G. Duman (Eds.), Educational Research and Practice (pp. 124-129). Sofia, Bulgaria: St. Kliment Ohridski University Press.

Dağlığlu, H. E., Dağlı, H., \& Kılıç, N. M. (2014). Okul öncesi eğitimi öğretmen adaylarının matematik eğitimi dersine karşı tutumlarının çeşitli değişkenler açısından incelenmesi [Examination of pre-school teacher candidates' attitudes towards mathematics education course in terms of various variables]. In Proceedings of the YILDIZ International Conference on Educational Research and Social Sciences Proceedings (pp. 293-304). İstanbul, Turkey, Pegem Akademi.

Dağlıŏlu, H. E., Genç, H., \& Dağlı, H. (2017). Gelişimsel açıdan okul öncesi dönemde matematik egitimi. [Developmental aspects of mathematics education in preschool period] In İ. Ulutaş (Ed.), Okul öncesi matematik eğitimi [Preschool math education], (pp. 12-36). Ankara, Turkey: Hedef CS.

Erdoğan, S. (2006). Altı yaş grubu çocuklarına drama yöntemi ile verilen matematik eğitiminin matematik yeteneğine etkisinin Incelenmesi [A study on the effect of mathematics education given with drama method to six-years-old children on mathematics ability]. (Doctoral Dissertation). Ankara University, Ankara, Turkey. Retrieved from https://tez.yok.gov.tr

Even, R., \& Tirosh, D. (1995). Subject-matter knowledge and knowledge about students as sourches of teacher presentations of the subject-matter. Educational Studies in Mathematics, 29(1), 1-20.

Fisher, P. H. (2004). Early math interest and the development of math skills: an understudied relationship. (Doctoral Dissertation). University of Massachusetts, USA.

Frary, R. B. (1989). Partial-credit scoring methods for multiple-choice tests. Applied Measurement in Education, 2(1), 79-96.

Gersten, R., Chard, D. J., Jayanthi, M., Baker, S. K., Morphy, P., \& Flojo, J. (2009). Mathematics instruction for students with learning disabilities: A meta-analysis of instructional components. Review of Educational Research, 79(3), 1202-1242.

Gifford, S. (2005). Teaching mathematics 3-5: developing learning in the foundation stage. London, United Kingdom: Open University Press. 
Gökkurt, B., \& Soylu, Y. (2016). Ortaokul matematik öğretmenlerinin matematiksel alan bilgilerinin incelenmesi: Prizma örneği [Examination of mathematical knowledge of secondary school mathematics teachers: Prism example]. Abant İzzet Baysal Üniversitesi Ë̆itim Fakültesi Dergisi, 16(2), 451-481.

Güven, B., Karataş, İ., Öztürk, Y., Arslan, S., \& Gürsoy, K. (2013). Okul öncesi öğretmenlerinin ve öğretmen adaylarının okul öncesi matematik eğitimine ilişkin inançların belirlenmesine yönelik bir ölçek geliştirme çalışması [A scale development study to determine the beliefs of preschool teachers and teacher candidates' about preschool mathematics education]. Ilkögretim Online, 12(4), 969-980.

Güven, Y. (1998). Kız ve erkek çocuklarda matematik yeteneği ve matematik başarısı konusunda okulöncesi ve ilkokul (ilköğretim) öğretmenlerinin görüşlerinin değerlendirilmesi [Evaluation of preschool and primary school teachers' views on mathematics ability and mathematics achievement in girls and boys]. Marmara Üniversitesi Atatürk Ĕ̌itim Fakültesi Ĕ̈itim Bilimleri Dergisi, 10, 121-138.

Hacısalihoğlu Karadeniz, M. (2011). Okul öncesi öğretmenlerinin sınıf içi matematik uygulamalarının okul öncesi eğitim programına uyumluluğu [Accordance of preschool teachers' classroom mathematics practices with preschool education program]. (Doctoral Dissertation), Karadeniz Technical University, Trabzon, Turkey.

Henniger, M. L. (1987). Learning mathematics and science through play. Childhood Education, 63(3), 167-171.

Jang, Y. J. (2013) Perspectives on mathematics education for young children (Doctoral dissertation). University of Illinois, USA.

Karakuş, H., Akman, B., \& Ergene, Ö. (2018). Matematiksel Gelişim İnanç Ölçeği'ni Türkçeye uyarlama çalışması [The Turkish Adaptation Study of the Mathematical Development Beliefs Scale]. Ĕgitim ve Ögretim Dergisi, 8(2), 211-228.

Karasar, N. (2012). Bilimsel araştırma yöntemi [Scientific research method]. Ankara, Turkey: Nobel.

Kilday, C. R. (2010). Factors affecting children's math achievement scores in preschool (Doctoral Dissertation). University of Virginia, USA.

Kline, R. B. (2016). Principles and practice of structural equation modeling (3rd ed.). New York, NY: Guilford.

Koç, F., Sak, R., \& Kayri, M. (2015). Okul öncesi eğitim programındaki etkinliklere yönelik öz-yeterlik inanç ölçeğinin geçerlik ve güvenirlik analizi [Validity and reliability analysis of self-efficacy beliefs scale for activities in preschool education program], İlkögretim Online, 14(4), 1416-1427. doi: http://dx.doi.org/10.17051/io.2015.50571

MacCallum, R. C., Widaman, K. F., Preacher, K. J., \& Hong, S. (2001). Sample size in factor analysis: the role of model error. Multivariate Behavioral Research, 36(4), 611-637.

Masters, G. N. (1988). The analysis of partial credit scoring. Applied Measurement in Education, 1(4), 279-297.

McCray, J. (2008). Pedagogical content knowledge for preschool mathematics: relationships to teaching practices and child outcomes (Doctoral Dissertation). Loyola University, Chicago, IL.

McCray J.S., \& Chen,J.Q. (2012). Pedagogical content knowledge for preschool mathematics: construct validity of a new teacher interview, Journal of Research in Childhood Education, 26(3), 291-307.

McGrath, C. (2010). Supporting early mathematical development. New York, NY: Routledge.

Metin, N. (1994). Okul öncesi dönemde matematik eğitimi ve etkinlik örnekleri [Math education and activity examples in preschool period]. Ş. Bilir (Ed.), Okul öncesi eğitimciler için el kitabı [Handbook for preschool educators]. Istanbul, Turkey: Ya-Pa. 
Milli Eğitim Bakanlığı (Turkish Ministry of National Education), (2013). Okul öncesi eğitim programı [Preschool education program]. Ankara, Turkey: Milli Eğitim Bakanlığı.

Mokrova, I. L. (2012). Motivation at preschool age and subsequent school success: role of supportive parenting and child temperament (Doctoral Dissertation). University of North Carolina, USA.

Mononen, R., \& Aunio, P. (2013). Early mathematical performance in Finnish kindergarten and grade one. Lumat, 1(3), 245-262.

Mononen, R., Aunio, P., \& Koponen, T. (2014). Investigating right start mathematics kindergarten instruction in Finland. Journal of Early Childhood Education Research, $3(1), 2-26$.

National Association for the Education of Young Children \& National Council of Teachers of Mathematics. (2010). Position statement. Early childhood mathematics: Promoting good beginnings. Retrieved from www.naeyc.org/resources/position_statements/psmath.htm

National Council of Teachers of Mathematics. (2000). Principles and Standards for school mathematics. Reston, VA: NCTM.

National Council of Teachers of Mathematics. (2009). Where We Stand. Reston, VA: NCTM. Retrieved from https://www.naeyc.org/files/naeyc/file/positions/ecmath.pdf

National Council of Teachers of Mathematics. (2013). Mathematics in Early Childhood Learning-NCTM position. Reston, VA: NCTM. Retrieved from http://www.nctm.org/uploadedFiles/Standards_and_Positions/Position_Statements/Earl y\%20Childhood\%20Mathematics\%20(2013).pdf

Nicol, C., \& Crespo, S. (2006). Learning to teach with mathematics textbooks: How pre-service teachers interpret and use curriculum materials. Educational Studies in Mathematics, 62(3), 331-355.

Nunnally, J. C. (1978). Psychometric theory. New York, NY: McGraw Hill.

Ontario Ministry of Education (OME). (2014). Doing Mathematics with Your Child, Kindergarten to Grade 6: A Parent Guide. Toronto, Ontario, Canada.

Parpucu, N., \& Erdoğan, S. (2017). Okul öncesi öğretmenlerinin sınıf uygulamalarında matematik dilini kullanma sıklıkları ile pedagojik matematik içerik bilgileri arasındaki ilişki [The relationship between the frequency of mathematical language and pedagogical mathematic content knowledge of preschool teachers]. Erken Çocukluk Çalışmaları Dergisi, 1(1), 19-32. Doi: 10.24130/eccd.jecs.19672017118

Platas, L. M. (2008). Measuring teachers' knowledge of early mathematical development and their beliefs about mathematics teaching and learning in the preschool classroom (Doctoral Dissertation). University of California, USA.

Sammons, P., Elliot, K., Sylva, K., Melhuish, E., Siraj-Blatchford, I., \& Taggart, B. (2004). The impact of pre-school on young children's cognitive attainment at entry to reception. British Educational Research Journal, 30(5), 691-712.

Shulman, L. S. (1986). Those who understand: Knowledge growth in teaching. Educational Research, 15(2), 4-14.

Şeker, P. T., \& Alisinanoğlu, F. (2015). A survey study of the effects of preschool teachers' beliefs and self-efficacy towards mathematics education and their demographic features on 48-60 month-old preschool children's mathematic skills. Creative Education, 6(3), 405-414. doi: $10.4236 /$ ce. 2015.63040

Tanışlı, D. (2013). İlköğretim matematik öğretmeni adaylarının pedagojik alan bilgisi bağlamında sorgulama becerileri ve ögrenci bilgileri [Preservice primary school mathematics teachers' questioning skills and knowledge of students in terms of pedagogical content knowledge]. Eğitim ve Bilim, 38(169), 80-95. 
Tella, A. (2007). The impact of motivation on student's academic achievement and learning outcomes in mathematics among secondary school students in Nigeria. Eurasia Journal of Mathematics, Science \& Technology Education, 3(2), 149-156.

Thorndike, R. M. (2005). Measurement and evaluation in psychology and education (7th ed.). Upper Saddle River, NJ: Pearson.

Türkiye İstatistik Kurumu Başkanlığı [Turkish Statistical Institute] (TÜİK). (2012). Gelir ve yaşam koşulları araştırması mikro veri seti (Kesit) [Income and living conditions research micro data set (Section)]. Ankara, Turkey: TÜIKK. Retrieved from http://www.tuik.gov.tr/MicroVeri/GYKA_2012/turkce/metaveri/siiniiflamalar/index.ht $\underline{\mathrm{ml}}$

Umay, A. (2003). Matematiksel muhakeme yeteneği [Mathematıcal Reasonıng Ability]. Hacettepe Üniversitesi Eğitim Fakültesi Dergisi, 24, 234-243.

Watts, T. W., Duncan, G. J., Clements, D. H., \& Sarama, J. (2017). What is the long-run impact of learning mathematics during preschool? Child Development, 89(2), 539-555. DOI: $10.1111 /$ cdev.12713

Yurdugül, H. (2005). Ölçek geliştirme çalışmalarında kapsam geçerliği için kapsam geçerlik indekslerinin kullanılması [Using scope validity indices for scope validity in scale development studies]. In Proceedings of the Pamukkale University, XIV. National Educational Sciences Congress, Pamukkale University, Denizli, Turkey.

Zhang, Y. (2015) Pedagogical content knowledge in early mathematics: what teachers know and how it associates with teaching and learning (Doctoral dissertation). Loyola University, Chicago, IL. 